\title{
Agro-waste: a potential fermentation substrate for Penicillium chrysogenum
}

\author{
B. M. ONYGEME-OKERENTA ${ }^{1}$, S. NWODO CHINEDU ${ }^{2 *}$, V. I. OKOCHI ${ }^{1}$ \\ and U. A. OKAFOR ${ }^{1}$
}
${ }^{I}$ Department of Biochemistry, College of Medicine, University of Lagos, PMB 12003 Idiaraba, Lagos, Nigeria.
${ }^{2}$ Department of Biological Sciences, College of Science and Technology, Covenant University, KM 10 Idiroko Road, Canaan Land, PMB 1023 Ota, Ogun State, Nigeria.
*Corresponding author, E-Mail: snchinedu@ covenantuniversity.com, sncresearch@gmail.com, Tel: +234(0)8028626 605

\begin{abstract}
Common agro-wastes found in Lagos, Nigeria (cassava shavings, corncob, sawdust, and sugarcane pulp) were compared with glucose and lactose as fermentation substrates for Penicillium chrysogenum PCL501. Cassava shavings significantly $(\mathrm{P}<0.001)$ produced the highest amount of mycelia weight $(0.43 \pm$ $0.02 \mathrm{mg} / \mathrm{ml}$ ) than all the other substrates. This was followed by corncob with peak mycelia weight of $0.33 \pm$ $0.02 \mathrm{mg} / \mathrm{ml}$. Peak mycelia weight of $0.27 \pm 0.01 \mathrm{mg} / \mathrm{ml}$ was equally obtained with glucose and sugarcane pulp whereas lactose gave a slightly lower peak of $0.25 \pm 0.01 \mathrm{mg} / \mathrm{ml}$. Sawdust gave the least mycelia weight of $0.13 \pm 0.01 \mathrm{mg} / \mathrm{ml}$. Total sugar content of all the culture media steadily decreased as fungal growth progressed indicating that the organism utilized carbohydrates for growth and mycelia formation. Cultures containing cassava shavings and sawdust gave high protein peaks of $0.84 \pm 0.05$ and $0.65 \pm 0.03 \mathrm{mg} / \mathrm{ml}$ respectively. Cultures containing corncob, glucose, lactose and sugarcane pulp yielded lower protein peaks of $0.37 \pm 0.02$, $0.30 \pm 0.02,0.24 \pm 0.02$ and $0.18 \pm 0.01 \mathrm{mg} / \mathrm{ml}$ respectively. The results suggest that cassava shavings, corncob and sugarcane pulp could serve as cheap fermentation substrates for the growth of the fungus. Of all the substrates investigated, cassava shavings have the best potential to serve as substrate for fermentation by Penicillium chrysogenum PCL501.
\end{abstract}

(C) 2009 International Formulae Group. All rights reserved.

Keywords: Agro-wastes, microbial substrate, Penicillium chrysogenum PCL501, growth, carbohydrate utilization.

\section{INTRODUCTION}

Cellulosic biomass in the form of crop residues and agro-industrial wastes are renewable carbon sources available in very large quantities both in industrialized and developing countries (Klugg and Reddy, 1984). They accumulate every year, particularly in major cities and settlements, causing enormous environmental pollution with adverse health, economic and social consequences (Andren et al., 1975; Funuoka et al., 1995). In Nigeria, agro-industrial wastes abound in the form of wood-wastes and crop residues such as cereal straws, cassava shavings, corncobs and sugarcane pulps (Abu et al., 2000). These residual plant materials can be converted into several value-added products and could serve as cheap carbon and energy sources for fermentation, thereby reducing pollution-load (Wu and Lee, 1997; Solomon et al., 1999; Howard et al., 2003). This underscores the growing interest on agroindustrial wastes as substrates in industrial fermentation processes.

Numerous filamentous fungi naturally thrive on plant wastes because they can 
penetrate the dead plant matter and utilize the cell wall components as growth substrates (Grant and Long, 1981). Among them is Penicillium species, a common contaminant which colonizes a wide range of materials including wood, fabrics and leather objects. While some species produce poisonous toxins or cause food spoilage, other species have been found to be beneficial to man. Among the useful species is Penicillium chrysogenum, the source of penicillin antibiotics (Volk, 2003). A strain of $P$. chrysogenum (PCL501) was isolated from wood-waste dump in Lagos, Nigeria by Nwodo-Chinedu et al. (2005). The organism produces extracellular enzymes such as cellulases (Nwodo-Chinedu et al., 2007a) and xylanases (Okafor et al., 2007; Chinedu et al., 2008) in media containing agro-wastes as sole carbon sources.

Cellulosic biomass in the form of residual plant materials are potential cheap carbon and energy sources for fermentation, which can replace refined carbohydrates such as glucose and lactose currently being used as fermentation substrates for penicillin production. This work compared the utilization of four major cellulosic waste materials produced in Nigeria by $P$. chrysogenum PCL501 for growth. This is with the view to assessing the potentials of the materials as low-cost sources of carbon and energy in fermentation processes involving $P$. chrysogenum.

\section{MATERIALS AND METHODS \\ Preparations of agro-waste materials}

Sawdust of Abora wood (Mitragyna ciliata) was collected from sawmills at Ikorodu, Lagos, Nigeria and dried in the oven at $80{ }^{\circ} \mathrm{C}$ for 2 hours. Mature sugarcane (Saccharum offinarum) stems, fresh maize (Zea mays) and cassava shavings (Manihot esculenta) were purchased from a local market in Mushin, Lagos. The crushed sugarcane pulp was soaked overnight and washed repeatedly in distilled water to remove residual simple sugars. Corncob was obtained by removing the maize grains. The materials were cut into small pieces and dried in the oven at $80{ }^{\circ} \mathrm{C}$ for 2 hours. These were milled using Marlex exceller grinder (Mumbai, India) and passed through a sieve of $0.5 \mathrm{~mm}$ pore size. Fine powder obtained was used for subsequent analysis.

\section{Organism}

The strain of $P$. chrysogenum (PCL501) used for this study was isolated from a wood-waste dump in Lagos, Nigeria and identified as described previously (Nwodo-Chinedu et al., 2005). The organism was maintained on potato dextrose agar slant at $4{ }^{\circ} \mathrm{C}$.

\section{Media Preparation}

A modification of the Mineral salt medium described by Kastner et al. (1994) was used for the studies. This liquid medium contained per litre of distilled water: Ammonium acetate, $6.0 \mathrm{~g} ; \mathrm{NaSO}_{3}, 0.5 \mathrm{~g}$; $\mathrm{ZnSO}_{4} .7 \mathrm{H}_{2} \mathrm{O}, 0.02 \mathrm{~g} ; \mathrm{MgSO}_{4} .7 \mathrm{H}_{2} \mathrm{O}, 0.25 \mathrm{~g}$; $\mathrm{KH}_{2} \mathrm{PO}_{4}, 6.0 \mathrm{~g} ; \mathrm{FeSO}_{4} .7 \mathrm{H}_{2} \mathrm{O}, 0.02 \mathrm{~g}$; and 10.0 $\mathrm{g}$ of the respective carbon source (glucose, lactose, Cassava shavings, corncob, sawdust and Sugarcane pulp). The $\mathrm{pH}$ was adjusted to 5.6 before autoclaving at $121{ }^{\circ} \mathrm{C}$ for 15 minutes.

\section{Fungal growth}

The organism was sub-cultured on PDA plates and incubated at $30{ }^{\circ} \mathrm{C}$ for $3-5$ days to obtain the spores used for inoculation. The spores were washed into a sterile beaker using $0.1 \%$ Tween 80 in $0.1 \mathrm{M}$ potassium phosphate buffer at pH 7.0 (Carter, 1977). The spore suspension was diluted such that the 1 in 10 dilution gave an optical density of 0.48 $(530 \mathrm{~nm})$. Five millimetres $(5 \mathrm{ml})$ of the spore suspension was used to inoculate $50 \mathrm{ml}$ of the respective sterile liquid medium placed in 250 $\mathrm{ml}$ Erlenmeyer flask. The flask was covered with sterile cotton wool and incubated at 30 ${ }^{\circ} \mathrm{C}$ with continuous agitation at $100 \mathrm{Osci} / \mathrm{min}$ using Griffin flask shaker. Cultures were harvested by filtration in triplicates at 3-day intervals over a 21-day period. The cell-free filtrates were used for sugar and protein analyses.

\section{Mycelia weight determination}

The mycelia was carefully removed, washed and dried to a constant weight in the oven at $70{ }^{\circ} \mathrm{C}$ for 2 hours (Kim et al., 2002; Park et al., 2002).

\section{Total sugar determination \\ Total sugar content of the cell-free filtrate was assayed using the Anthrone}


method as described by Morris (1948), with glucose as standard.

\section{Protein assay}

Protein content of the cell-free culture filtrate was assayed using folin ciocalteau method described by Lowry et al. (1951) with bovine serum albumin (BSA) as standard.

\section{Data analysis}

All assays were done in triplicates. The results are expressed as Mean \pm standard error of mean (SEM). Significant difference between values was determined by Fisher's protected least significant different $t$-test with two-tail probabilities of less than 0.05 considered significant. Statistical significant difference in the rate of microbial growth between media types was assessed by a oneway analysis of variance.

\section{RESULTS}

\section{Growth of organism}

Figure 1 shows the mycelia weight of $P$. chrysogenum (PCL501) cultivated in media containing the different substrates. There was a general increase in mycelia weight as incubation progressed until it attained a maximum value after which it began to decline. The period for maximum mycelia weight varied with the substrates. It was 15 days for glucose, cassava shavings, and sugarcane pulp whereas it was 18 days for lactose, corncob and sawdust. All the substrates supported the growth of the organism. Best growth was obtained with cassava shavings which yielded the highest mycelia weight of $0.43 \pm 0.02 \mathrm{mg} / \mathrm{ml}$; followed by corncob with a peak mycelia weight of $0.33 \pm 0.02 \mathrm{mg} / \mathrm{ml}$. Both glucose and sugarcane pulp yielded a peak mycelia weight of $27 \pm 0.01 \mathrm{mg} / \mathrm{ml}$ whereas lactose gave a maximum mycelia weight of $25 \pm 0.01$ $\mathrm{mg} / \mathrm{ml}$. Sawdust gave the least growth with a maximum mycelia growth of $0.13 \pm 0.01$ $\mathrm{mg} / \mathrm{ml}$.

\section{Carbohydrate utilization}

Carbohydrate utilization by $P$. chrysogenum (PCL501) cultivated on the different substrates is shown in figure 2. Cellfree media containing cassava shavings gave the highest total sugar content of $4.25 \pm 0.04$ $\mathrm{mg} / \mathrm{ml}$ before the incubation whereas that of corncob gave the least value of $2.98 \pm 0.02$ $\mathrm{mg} / \mathrm{ml}$. Cell-free media containing glucose, lactose and sugarcane pulp contained about the same amount of total sugar $(3.82 \pm 0.01$ $\mathrm{mg} / \mathrm{ml}$ ) while that of sawdust contained $3.58 \pm$ $0.01 \mathrm{mg} / \mathrm{ml}$. The cell-free media had the highest concentration of sugar, which gradually reduced as fungal growth progressed. Sawdust showed the most rapid decline, approaching zero after 15 days; there was no detectable sugar in the media afterwards. At the end of the 21-day period of incubation, cassava shavings had the highest residual sugar content of $1.98 \pm 0.01 \mathrm{mg} / \mathrm{ml}$.

\section{Protein yield}

The protein yield of $P$. chrysogenum cultivated on the different substrates is shown in figure 3. The protein released by the organism in the different media rose steadily to a maximum value on the $12^{\text {th }}$ day, after which it gradually began to decrease. Culture containing cassava shavings gave the highest protein peak of $0.84 \mathrm{mg} / \mathrm{ml}$ followed by sawdust with $0.65 \mathrm{mg} / \mathrm{ml}$. A peak protein yield of $0.37, \quad 0.30$ and $0.24 \mathrm{mg} / \mathrm{ml}$ respectively was obtained with corncob, glucose and lactose. The least peak was 0.18 $\mathrm{mg} / \mathrm{ml}$ obtained with sugarcane pulp.

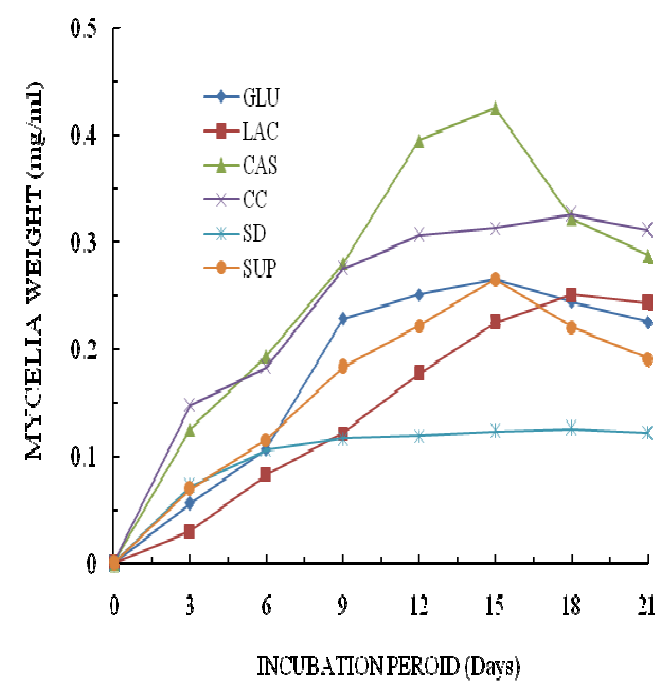

Figure 1: Mycelia weight of Penicillium chrysogenum PCL501 fermented in media containing different substrates over a period of 21 days at $30{ }^{\circ} \mathrm{C}$ and $\mathrm{pH}$ 5.6. $(\mathrm{GLU}=$ Glucose, $\mathrm{LAC}=$ Lactose, $\mathrm{CAS}=$ Cassava shavings, $\mathrm{CC}=\mathrm{Corncob}$, $\mathrm{SD}=$ Sawdust, $\mathrm{SUP}=$ Sugarcane pulp). 


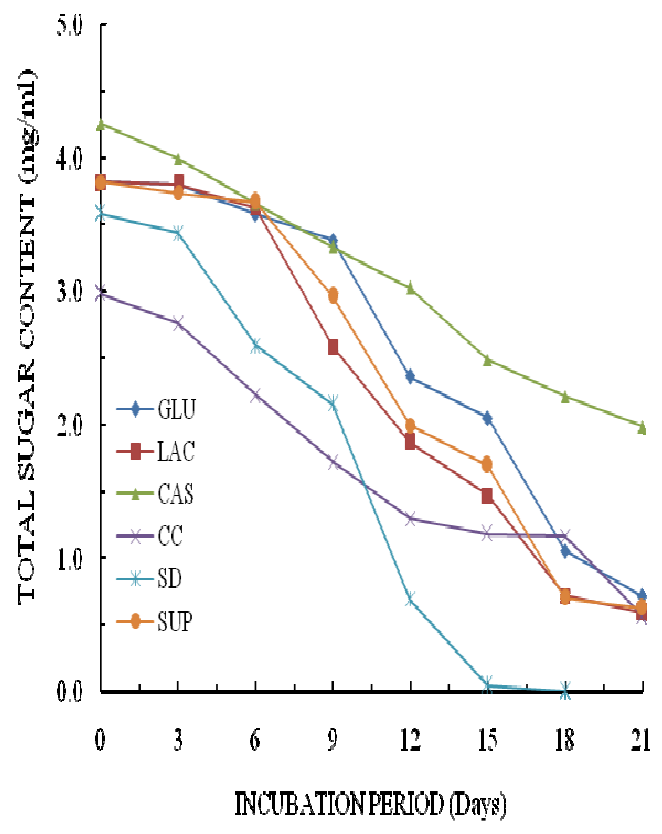

Figure 2: Total sugar contents of cell-free culture filtrates of Penicillium chrysogenum PCL501 fermented for 21 days using different substrates at $30{ }^{\circ} \mathrm{C}$ and $\mathrm{pH}$ 5.6. ( $\mathrm{GLU}=$ Glucose, LAC $=$ Lactose, $\mathrm{CAS}=$ Cassava shavings, $\mathrm{CC}=$ Corncob, $\mathrm{SD}=$ Sawdust, $\mathrm{SUP}=$ Sugarcane pulp).

\section{DISCUSSION}

All the agro-wastes supported the growth of the fungus judging from the development of mycelia. A statistically significant difference in growth rate exists between the medium containing cassava shavings and sawdust-containing medium $(\mathrm{P}<0.05)$. Interestingly, cassava shavings and corncob produced more mycelia than glucose whereas sugarcane pulp produced as much mycelia as glucose. A significant difference $(\mathrm{P}<0.001)$ in mycelia growth was observed between the media containing cassava shavings, corncob and glucose. The growth in glucose containing media did not statistically differ from that containing sugarcane pulp. This implies that the three agro-wastes (cassava shavings, corncob and sugarcane) are viable low-cost substrates for the cultivation of the fungus. In this work, the growth of $P$. chrysogenum PCL501 was found to be slightly higher using glucose in comparison to lactose. In a comparative study of the growth of $P$. chrysogenum NCAIM 00237 strain in different carbon sources, good growth was observed with glucose, sucrose, glycerol and galactose, while growth on lactose was substantially slower (Nagy et al., 2001). Cassava shavings, in particular, yielded 1.6 1.7 times as much mycelium as glucose and lactose. This is very significant considering the fact that glucose is an easily metabolizable sugar which plays a central role in energy metabolism of most forms of life. $P$. chrysogenum PCL501 has also been reported to yield very high amount of mycelia in glucose-containing medium and to thrive on agar media supplemented with sawdust and sugarcane pulp as sole carbon sources (Nwodo-Chinedu et al., 2007a, 2007b). Cellfree filtrate containing cassava shavings also contained the highest amount of total sugar compared to all the other substrates used in this study. This implies that the substrate is a rich carbon and energy resource which the organism can easily utilize for energy and growth. The least growth was obtained with sawdust. Sawdust is known to produce very small amount of mycelia of $P$. chrysogenum compared to glucose (Nwodo-Chinedu et al., 2007b). A rapid decrease in sugar content of the culture media containing sawdust was noted during the growth of the fungus; it was such that there was no detectable sugar in the media after the $15^{\text {th }}$ day of incubation (Figure 2 ). This means that the substrate is a poor source of carbon and energy for the growth of fungus. Sawdust of Abora wood (Mitragyna ciliata) contains over $60 \%$ crude fiber consisting of a large proportion of lignin (Grant and Long, 1981; Okafor et al., 2007).

The sugar content of all the culture media steadily decreased as fungal incubation and mycelia weight increased. This indicates that the organism utilized carbohydrates available in the substrates for growth and mycelia formation. A similar observation was reported by Park et al. (2002) in the study of exobiopolymer production and mycelial morphology in Cordyceps militaris. Since the major carbohydrates found in the agro-wastes are structural polysaccharides of the secondary plant cell wall (cellulose and hemicelluloses), it means that the organism produces hydrolytic enzymes necessary for their breakdown. P. chrysogenum PCL501 has been shown to produce cellulases (NwodoChinedu et al., 2007a) and xylanases (Okafor et al., 2007; Chinedu et al., 2008) required for the hydrolysis of cellulosic biomass. 




Figure 3: Protein released by Penicillium chrysogenum PCL501 fermented in media containing different substrates over a period of 21 days at $30{ }^{\circ} \mathrm{C}$ and $\mathrm{pH} 5.6$. (GLU $=$ Glucose, $\mathrm{LAC}=\mathrm{Lactose}, \mathrm{CAS}=$ Cassava shavings, $\mathrm{CC}=$ Corncob, $\mathrm{SD}=$ Sawdust, $\mathrm{SUP}=$ Sugarcane pulp).

The organism secreted extracellular proteins which were present in the cell-free culture filtrate (Figure 3). These proteins may be functioning as transport proteins or hydrolytic enzymes. $P$. chrysogenum is known to produce a number of hydrolytic enzymes (Nuero and Reyes, 2002). The protein released by the organism in the different media rose steadily to a maximum value after which it gradually began to decrease. This is similar to the pattern of mycelia growth. The protein peaks of cultures containing cassava shavings and sawdust were significantly $(\mathrm{P}<0.05)$ higher than that obtained with glucose. Cassava shavings contain some amount of starch in addition to the fibrous structural polysaccharides. This gives the organism varied options for glucose generation. Amylases as well as several cellulolytic enzymes could be part of the proteins secreted in the media containing cassava shavings. Sawdust is known to trigger the release of large amounts of proteins by $P$. chrysogenum PCL501 (Nwodo-Chinedu et al., 2007a; Okafor et al., 2007).

In conclusion, common agro-wastes found in Lagos, Nigeria (cassava shavings, corncob, sawdust, and sugarcane pulp) supported the growth of Penicillium chrysogenum PCL501. Three of the agro- wastes, cassava shavings, corncob and sugarcane pulp, compared favorably with glucose and lactose as fermentation substrates for cultivating the organism. The agro-wastes were well utilized by the organism and can serve as cheap carbon sources for the growth of the fungus. Of all the substrates investigated, cassava shavings appear to be the best substrate for cultivating the organism. The substrate was better than glucose in terms of total sugar content and mycelia production. The prospect for the use of the agro-waste in penicillin production is indicated. Cassava shavings are abundantly produced during the processing of cassava into various consumable products such as garri and fufu. The use of the agro-waste in large scale fermentation will not only turn the waste into a valuable resource but also help reduce the environmental pollution due to the cellulosic biomass.

\section{REFERENCES}

Abu EA, Onyenekwe PC, Ameh DA, Agbaji AS, Ado SA. 2000. Cellulase (EC 3.2.1.3) production from sorghum bran by Aspergillus niger SL1: An assessment of pretreatment methods. Proceedings of the International Conference on Biotechnology. Commercialization and Food security. Abuja, Nigeria; 53-157. 
Andren RK, Mandels MH, Medeiros JB. 1975. Production of sugars from waste cellulose by enzymatic hydrolysis I. Primary evaluation of substrates. Appl. Poly. Symp., 28: 205-219.

Chinedu Nwodo S, Okafor UA, Emezue TN, Okochi VI. 2008. Xylanase production of Aspergillus niger and Penicillium chrysogenum from ammonia pretreated cellulosic waste. Res. J. Microbiol., 3(4): 246-253.

Funuoka M, Matsubara M, Seki N, Fukatsu S. 1995. Conversion of native lignin to a highly phenolic functional polymer and its separation from lignocelluloses. Biotech. Bioeng., 46: 545-552.

Grant WD, Long PE. 1981. The carbon cycle. In Environmental Microbiology. Thomas Litho Ltd.: Scotland; 91-116.

Howard RLI, Abotsi E, Jansen Van Rensburg, ELI, Howard S. 2003. Lignocellulose biotechnology: issues of bioconversion and enzyme production. Review. Afri J. Biotechnol., 2(12): 602-619.

Kastner M, Brewer-Jammali M, Mahroe B. 1994. Enumeration and characterization of the soil microflora from hydrocarbon contaminated soil sites able to mineralize PAH. Appl. Microbiol. Biotechnol., 41: 267-273.

Kim SW, Hwang HJ, Park JP, Cho YJ, Song CH, Yun JW. 2002. Mycelial growth and exo-biopolymer production by submerged culture of various edible mushrooms under different media. The Society for Applied Microbiology. Lett. Appl. Microbiol., 34: 56-61.

Klugg MJ, Reddy CA. 1984. Current prospective in microbial ecology. Am. Soc. Microbiol., 572.

Lowry OH, Rosebrough NJ, Farr AL, Randall RJ. 1951. Protein measurement with the folin-phenol reagent. J. Biol. Chem., 193: 265-275.

Miller GL. 1959. Use of dinitrosalicyclic reagent for the determination of reducing sugars. Analytical Chemistry, 31: 426428.

Morris DL. 1948. Determination of carbohydrate in biological fluids. Science, 107: 254.

Nagy Z, Keresztessy Z, Szentirmai A, Biro S. 2001. Carbon source regulation of beta galactosidase biosynthesis in Penicillium chrysogenum. J. Basic Microbiol., 41(6): 321-362.

Nwodo-Chinedu S, Okochi VI, Smith HA, Omidiji O. 2005. Isolation of cellulolytic microfungi involved in wood-waste decomposition: Prospect for enzymatic hydrolysis of cellulosic wastes. Int $J$. Biomed. Health Sci., 1(2): 41-51.

Nwodo-Chinedu S. Okochi VI, Smith HA, Okafor UA, Onyegeme-Okerenta BM, Omidiji O. 2007a. Effect of carbon sources on cellulase (EC 3. 2. 1. 4) production by wild-type Penicillium chrysogenum PCL501. Afri. J. Biochem. Res., 1(1): 6-10.

Nwodo-Chinedu S, Okochi VI, Omidiji O, Omowaye OO, Adeniji BR, Olukoju D, Chidozie F. 2007b. Potentials of cellulosic wastes in media formulation. Afr. J. Biotechnol., 6(3): 243-246.

Nuero OM, Reyes F. 2002. Enzymes for animal feeding from Penicillium chrysogenum mycelial wastes from penicillin manufacture. Lett. Appl. Microbiol., 34: 413-416.

Okafor UA, Emezue TN, Okochi VI, Onyegeme-Okerenta BM, NwodoChinedu S. 2007. Xylanase production by Penicillium chrysogenum PCL501 fermented on cellulosic wastes. Afri. J. Biochem. Res., 1(4): 048-053.

Park, JP, Kim YM, Kim SW, Hwang HJ, Cho YJ, Lee1 YS, Song CH, Yun JW. 2002. Effect of agitation intensity on the exobiopolymer production and mycelial morphology in Cordyceps militaris. The society for applied microbiology, Lett. Appl. Microbiol., 34: 433-438.

Solomon BO, Amigun B, Betiku E, Ojumu TV, Layokun SK. 1999. Optimization of cellulose production by Aspergillus flavus Linn Isolate NSPR101 Grown on Bagasse. JNSCHE, 16: 61-68.

Volk TJ. 2003. Tom Volk's Fungus of the Month for November 2003. TomVolkFungi.net, University of Wisconsin-La Crosse.

Wu Z, Lee YY. 1997. Inhibition of the enzymatic hydrolysis of cellulose by ethanol. Biotechnol. Lett., 19: 977-979. 